\title{
Frictional properties of the shallow Nankai Trough accretionary sediments dependent on the content of clay minerals
}

\author{
Miki Takahashi', Shuhei Azuma ${ }^{2,3}$, Hidenori Ito ${ }^{2}$, Kyuichi Kanagawa ${ }^{2 *}$ and Atsuyuki Inoue ${ }^{2}$
}

\begin{abstract}
We conducted triaxial friction experiments on the shallow Nankai Trough accretionary sediments at confining pressures, pore water pressures, temperatures close to their in situ conditions, and axial displacement rates $\left(V_{\text {axial }}\right)$ changed stepwise among $0.1,1$, and $10 \mu \mathrm{m} / \mathrm{s}$. The results revealed that their frictional properties change systematically according to the content of clay minerals, smectite in particular. The steady-state friction coefficient $\left(\mu_{\mathrm{ss}}\right)$ at $V_{\text {axial }}=1 \mu \mathrm{m} / \mathrm{s}$ decreases with increasing clay mineral content, shown in weight percent, from 0.82 for a sandstone sample ( $6 \mathrm{wt} \%)$, through 0.71 for a tuff sample $(\approx 17 \mathrm{wt} \%)$, and 0.53 to 0.56 for siltstone samples (29 to $34 \mathrm{wt} \%)$, to 0.25 for a claystone sample (42 wt\%). Slip-dependent frictional behavior changes accordingly from slip hardening for the sandstone sample, through quasi steady-state slip for the tuff and siltstone samples, to distinct slip weakening for the claystone sample. Although all samples exhibit velocity-strengthening behavior upon stepwise changes in sliding velocity, the ratio of the $(a-b)$ value to the velocity dependence of steady-state friction $\left(\Delta \mu_{s s} / \Delta \ln V_{\text {sliding }}\right)$ decreases with increasing clay mineral content, which implies that the friction component decreases while the flow component increases accordingly. Thus, faulting in the shallow Nankai Trough accretionary prism is likely controlled by the clay mineral content, in particular the smectite content, in the sediments as well as in the fault zones.
\end{abstract}

Keywords: Accretionary sediments; Nankai Trough; Friction; Clay mineral content

\section{Background Introduction}

Sediments on the incoming oceanic plate at subduction zones are mainly composed of hemipelagic sediments and terrigenous turbidites, which, together, are scraped off to form an accretionary prism (e.g., Underwood 2007). This is also true in the Nankai Trough subduction zone, as revealed by the recent Integrated Ocean Drilling Program (IODP) Expeditions 316, 322, and 333 (Screaton et al. 2009; Underwood et al. 2010; Expedition 333 Scientists 2012), part of the Nankai Trough Seismogenic Zone Experiment (NanTroSEIZE). NanTroSEIZE IODP Expeditions 315, 316, 319, and 338 also revealed that the shallow ( $\leq 2,000 \mathrm{~m}$ below the seafloor) Nankai Trough accretionary prism is largely composed of claystone with subordinate siltstone, sandstone, and tuff (Ashi et al. 2009;

\footnotetext{
* Correspondence: kyu kanagawa@faculty.chiba-u.jp

${ }^{2}$ Department of Earth Sciences, Chiba University, Chiba 263-8522, Japan Full list of author information is available at the end of the article
}

Screaton et al. 2009; Expedition 319 Scientists 2010; Strasser et al. 2014). In order to evaluate the frictional properties of accretionary sediments in the Nankai Trough, friction experiments have therefore been conducted exclusively on cored mudstone (siltstone and claystone) samples (Hirose et al. 2008; Ikari et al. 2009, 2013; Ujiie and Tsutsumi 2010; Ikari and Saffer 2011; Tsutsumi et al. 2011; Takahashi et al. 2013). However, frictional properties of minor lithologies should also be investigated in order to fully evaluate the frictional properties of accretionary sediments. Here, we report the results of triaxial friction experiments on sandstone, tuff, and siltstone samples cored from the shallow Nankai Trough accretionary prism, in addition to experiments performed on claystone and siltstone samples already reported by Takahashi et al. (2013). Their frictional properties are found to change systematically according to their content of clay minerals, in particular of smectite. 


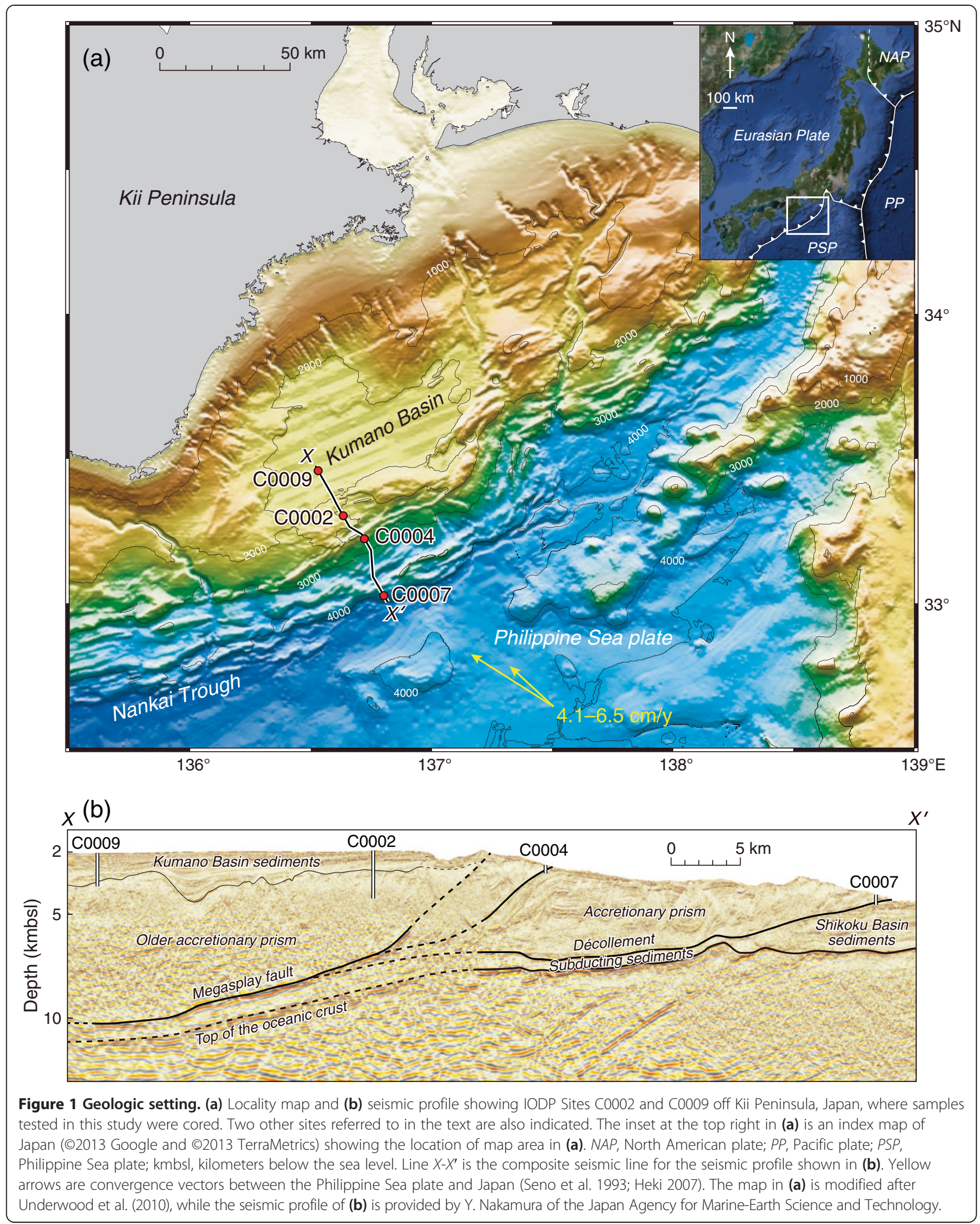




\section{Geologic setting}

The Nankai Trough is a convergent plate margin where the Philippine Sea plate is subducting northwestward beneath the Eurasian plate at a rate of 4 to $6.5 \mathrm{~cm} /$ year (Seno et al. 1993; Heki 2007; Figure 1). An accretionary prism is developed landward of the Nankai Trough (Figure 1). The Shikoku Basin sediments, composed of hemipelagic sediments and terrigenous turbidites, are actively accreting at the deformation front (Screaton et al. 2009; Underwood et al. 2010; Figure 1b). An insequence thrust package of accreted sediments occupies the space between this deformation front and the outer ridge (Figure $1 \mathrm{~b}$ ). The outer ridge was likely formed by out-of-sequence thrusting along the 'megasplay' fault

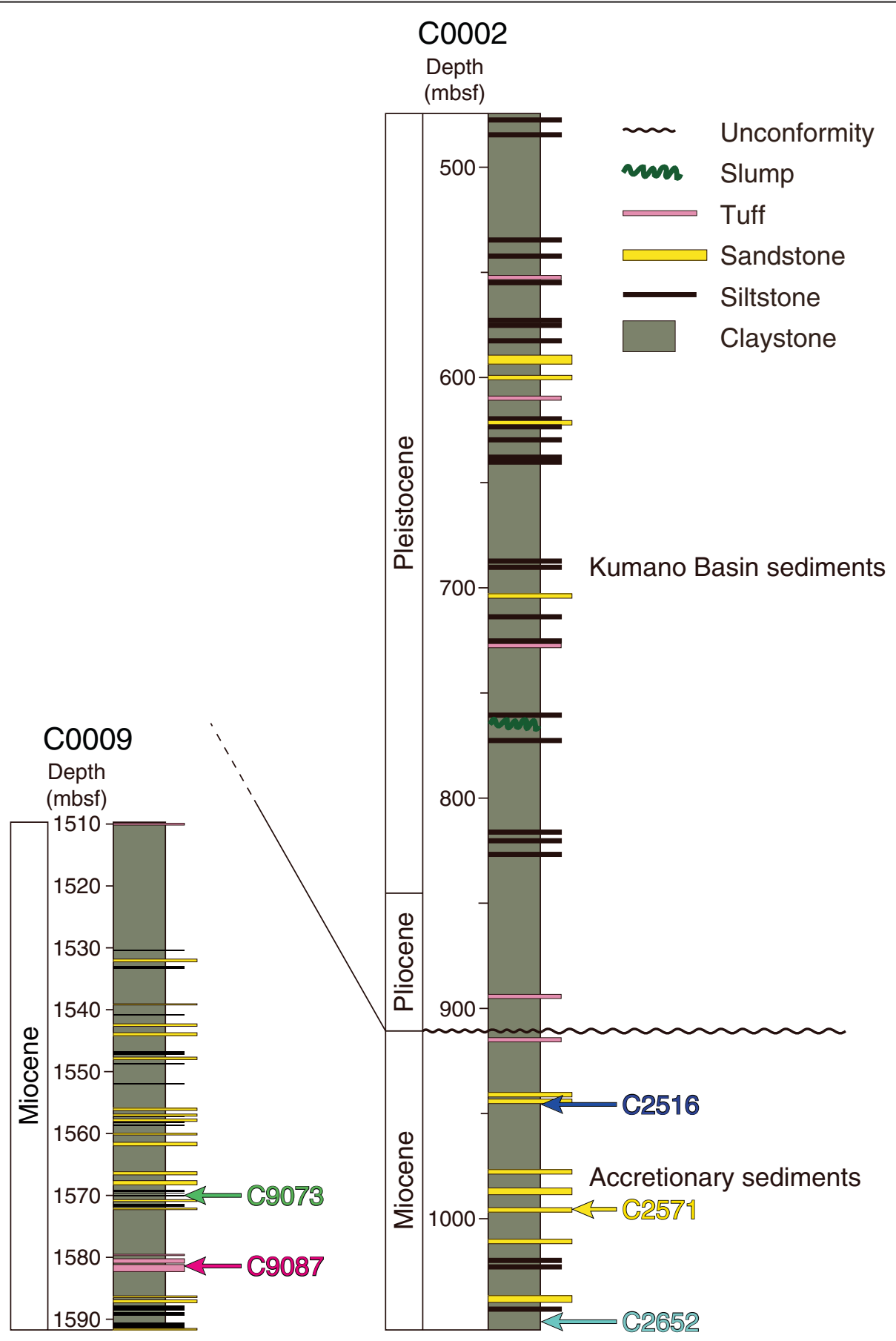

Figure 2 Locations of the five samples tested in this study. Columnar sections of Hole B at Site C0002 (right; Expedition 315 Scientists 2009) and Hole A at Site C0009 (left; Expedition 319 Scientists 2010). mbsf, meters below the seafloor. 
branching from the master décollement (Park et al. 2002; Moore et al. 2007; Figure 1b). Landward from this outer ridge off Kii Peninsula, the forearc Kumano Basin sediments unconformably cover the older accreted sediments (Figure 1b).

The Nankai Trough subduction zone has been the site of recurring, typically tsunamigenic great earthquakes larger than $M_{\mathrm{w}}>8.0$, including the 1944 Tonankai $M_{\mathrm{w}}$ 8.2 and 1946 Nankai $M_{\mathrm{w}} 8.3$ earthquakes (Ando 1975; Hori et al. 2004). Recent tsunami and seismic waveform inversions, seismic reflection studies, and mud breccia analyses suggest that the coseismic slip during the 1944 Tonankai earthquake occurred along the megasplay fault (Tanioka and Satake 2001; Park et al. 2002; Kikuchi et al. 2003; Sakaguchi et al. 2011; Park and Kodaira 2012). In addition, slow slip events or very low frequency earthquakes have recently been found to occur not only within the accretionary prism, but also along the décollement between the outer ridge and the deformation front (Ito and Obara 2006; Sugioka et al. 2012). The recently installed Dense Oceanfloor Network System for Earthquakes and Tsunamis (DONET) has begun to monitor the seismic activity around this region in detail (Nakano et al. 2013).

\section{Location and in situ conditions of samples tested}

We tested five samples of four different lithologies cored by D/V Chikyu from Hole B at Site C0002 and Hole A at Site C0009, both located in the Kumano Basin, during IODP Expeditions 315 and 319 (Figure 1). The unconformity boundary between the Miocene accretionary sediments and the overlying Pliocene-Pleistocene Kumano Basin sediments occurs at $\approx 922$ mbsf (meters below the seafloor) in Hole B at Site C0002 and at $\approx 1,285 \mathrm{mbsf}$ in Hole A at Site C0009 (Figures 1b and 2; Expedition 315 Scientists 2009; Expedition 319 Scientists 2010). Samples C2516, C2571, and C2652 come from 944.64, 995.52, and 1,048.99 mbsf, respectively, of Hole B at Site C0002, while samples C9073 and C9087 come from 1,569.99 and 1,581.40 mbsf, respectively, of Hole A at Site C0009 (Figure 2; Table 1). Samples C2516 and C2652 have already been tested by Takahashi et al. (2013), and samples C2571, C9073, and C9087 were additionally tested in this study.
According to temperature profiles estimated based on down hole temperatures and thermal conductivity on cores and cuttings measured at Sites C0002 and C0009 (Expedition 315 Scientists 2009; Expedition 319 Scientists 2010), in situ temperatures of samples C2516, C2571, and C2652 from Site C0002 are estimated to be $33^{\circ} \mathrm{C}$ to $35^{\circ} \mathrm{C}$, while those of samples C9073 and C9087 from Site $\mathrm{C} 0009$ are estimated to be $\approx 47^{\circ} \mathrm{C}$ (Table 1 ). From the overburden stresses calculated from the leastsquares fitted profiles of densities measured onboard D/ V Chikyu (Expedition 315 Scientists 2009; Expedition 319 Scientists 2010) and the water column above the seafloor, in situ pressures of samples C2516, C2571, and C2652 from Site C0002 are estimated to be 36 to $38 \mathrm{MPa}$, while those of samples C9073 and C9087 from Site C0009 are estimated to be $\approx 57 \mathrm{MPa}$ (Table 1). Assuming a hydrostatic condition, which was found to be true down to 1,460 mbsf from testing at Site C0009 during IODP Expedition 319 (Expedition 319 Scientists 2010), in situ pore pressures of samples C2516, C2571, and C2652 from Site C0002 are estimated to be 28 to $29 \mathrm{MPa}$, while those of $\mathrm{C} 9073$ and C9087 from Site C0009 are estimated to be $\approx 43 \mathrm{MPa}$ (Table 1 ).

\section{Methods}

\section{Sample characterization}

We prepared petrographic thin sections of the samples and observed their optical microstructures. We also conducted powder X-ray diffraction analyses of the samples. After qualitative analyses to check the constituent minerals, we conducted quantitative analyses following the method described by Chung (1974). We used quartz as the reference mineral and prepared a powder mixture of equal weights of synthetic quartz and each constituent mineral within the sample to be analyzed. From an $\mathrm{X}$-ray diffraction profile of each mixture, the peak-height ratio of a specific diffraction plane of each mineral to that of quartz was obtained. The peak-height ratio of the same diffraction planes from an X-ray diffraction profile of the sample to be analyzed then provides an estimate of relative weight of that specific mineral with respect to quartz. This method, although not very precise, gives a rough estimate of the modal composition in weight percent.

Table 1 Estimated in situ temperatures $(T)$, pressures $(P)$, and pore pressures $\left(P_{p}\right)$ of the five samples tested

\begin{tabular}{|c|c|c|c|c|c|}
\hline Sample & Site/hole/core/section & Depth (mbsf) & $T\left({ }^{\circ} \mathrm{C}\right)$ & $P(\mathrm{MPa})$ & $P_{\mathrm{p}}(\mathrm{MPa})$ \\
\hline C2516 & $\mathrm{C} 0002 / \mathrm{B} / 51 \mathrm{R} / 6$ & 944.64 & 32.6 & 36.2 & 28.3 \\
\hline C2571 & $\mathrm{C} 0002 / \mathrm{B} / 65 \mathrm{R} / 2$ & 995.52 & 33.8 & 37.2 & 28.8 \\
\hline C2652 & $\mathrm{C} 0002 / \mathrm{B} / 65 \mathrm{R} / 2$ & $1,048.99$ & 35.2 & 38.3 & 29.3 \\
\hline C9073 & C0009/A/7R/3 & $1,569.99$ & 46.8 & 57.1 & 42.9 \\
\hline C9087 & C0009/A/8R/7 & $1,581.40$ & 47.1 & 57.3 & 43.0 \\
\hline
\end{tabular}


In addition, we measured the porosities of the samples using a mercury bath and a helium porosimeter for bulk and pore volume measurements, respectively, at the Technology and Research Center of the Japan Oil, Gas, and Metals National Corporation.

\section{Experimental methods}

For the triaxial friction experiments, we used a gasmedium, high-pressure, high-temperature triaxial apparatus at the Active Fault and Earthquake Research Center of the Geological Survey of Japan (Masuda et al. 2002). The pressure media for confining and pore pressures were argon gas and distilled water, respectively. Hollow pistons enabled pore water to flow through the specimen being tested. Two independent servo-controlled pressure intensifiers enabled us to apply both confining and pore pressures of up to $200 \mathrm{MPa}$. The axial load was measured by a load cell attached to the lower piston inside the pressure vessel.
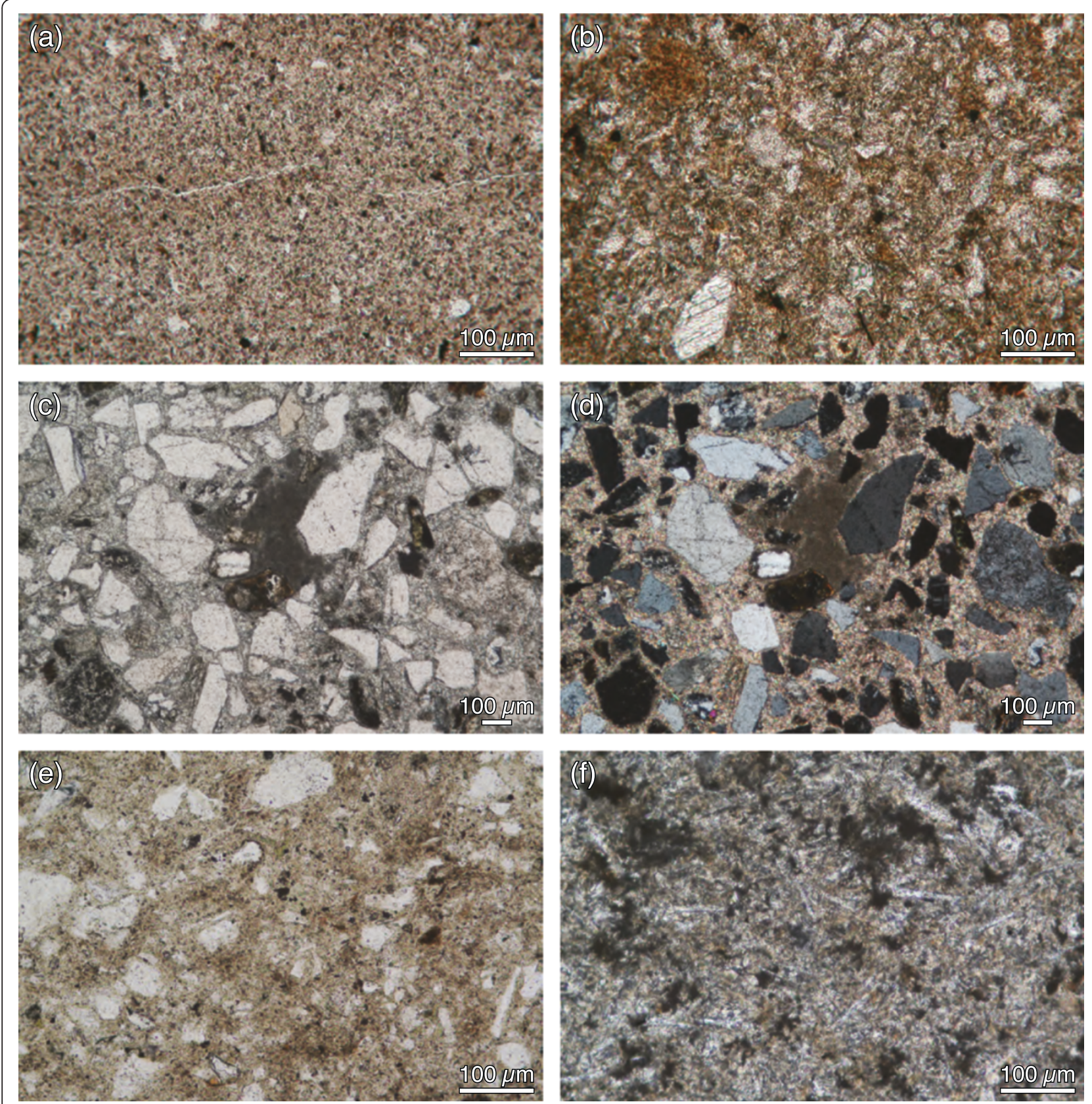

Figure 3 Microstructures of the five samples tested in this study. All except for (d) are optical micrographs taken under plane polarized light, while (d) is an optical micrograph taken under crossed polarized light. (a) Claystone sample C2516, (b) siltstone sample C2652, (c, d) sandstone sample C2571, (e) siltstone sample C9073, and (f) tuff sample C9087. 
We prepared simulated gouges with grain sizes smaller than $250 \mu \mathrm{m}$ from crushed and sieved core samples. As described in Takahashi et al. (2013), the specimen assembly consisted of a cylinder of porous Shirahama sandstone, $20 \mathrm{~mm}$ in diameter and $40 \mathrm{~mm}$ in length, containing a 0.65 -g ( $\approx 0.5$-mm-thick) gouge layer along a sawcut inclined $30^{\circ}$ to the cylinder axis; a pair of porous tungstencarbide spacers; a pair of alumina spacers; and upper and lower stainless-steel pistons. This assembly was then jacketed by a heat-shrink Teflon ${ }^{\bullet}$ tube.

We conducted friction experiments on simulated gouges as prepared above at a room temperature $\left(\approx 15^{\circ} \mathrm{C}\right)$, confining and pore pressures close to their in situ conditions (Table 1), and axial displacement rates $\left(V_{\text {axial }}\right)$ changed stepwise among $0.1,1$, and $10 \mu \mathrm{m} / \mathrm{s}$, i.e., at sliding velocities $\left(V_{\text {sliding}}\right)$ along the sawcut changed stepwise among $0.1155,1.155$, and $11.55 \mu \mathrm{m} / \mathrm{s}$, and monitored the differential stress with increasing axial displacement. Although the experimental temperature was $20^{\circ} \mathrm{C}$ to $30^{\circ} \mathrm{C}$ lower than the in situ temperatures (Table 1 ), the difference is very small at this temperature range and duration time of the experiments. We have thus conducted experiments at confining pressures, pore water pressures, and temperatures close to their in situ conditions. Shear and normal stresses acting on the gouge layer were calculated from the differential stress and effective confining pressure, and corrected for the Teflon ${ }^{\odot}$ jacket strength. Their ratio gives the friction coefficient $(\mu)$ of the gouge. The axial displacement was converted into sliding displacement $(d)$ along the sawcut.

\section{Results}

\section{Sample descriptions}

Sample C2516 is a very fine-grained (mostly $\leq 5 \mu \mathrm{m}$ ), homogeneous claystone (Figure 3a), as described in Takahashi et al. (2013). It contains $13 \mathrm{wt} \%$ quartz, $23 \mathrm{wt} \%$ feldspar, and $\approx 12 \mathrm{wt} \%$ hornblende as clastic grains, and 32 wt $\%$ smectite, $\approx 6 \mathrm{wt} \%$ illite, $1.5 \mathrm{wt} \%$ chlorite, and $\approx 3$ wt $\%$ kaolinite as clay minerals (Table 2 ). The porosity of this sample is $11.2 \%$, which is unusually low compared with the $30 \%$ to $50 \%$ porosities of accretionary

\begin{tabular}{|c|c|c|c|c|c|c|c|c|c|c|c|}
\hline Sample & Qz & Fs & Cc & $\mathrm{Hb}$ & $\mathrm{Pr}$ & Gs & Smt & III & Chl & Kln & Glass \\
\hline C2516 & 13.0 & 23.0 & 3.4 & 11.6 & 5.9 & 1.2 & 32.0 & 5.8 & 1.5 & 2.7 & 0.0 \\
\hline C2571 & 32.0 & 38.7 & 12.9 & 9.4 & 0.9 & 0.0 & 0.0 & 3.3 & 0.0 & 2.4 & 0.0 \\
\hline C2652 & 27.6 & 24.2 & 2.7 & 8.3 & 3.1 & 0.0 & 24.7 & 6.4 & 1.1 & 1.9 & 0.0 \\
\hline C9073 & 31.8 & 32.3 & 4.9 & 0.0 & 1.6 & 0.0 & 21.6 & 4.6 & 0.0 & 3.2 & 0.0 \\
\hline C9087 & 8.2 & 8.0 & 1.4 & 0.0 & 1.3 & 0.0 & 11.7 & 3.2 & 0.0 & 2.3 & 63.9 \\
\hline
\end{tabular}

Qz, quartz; Fs, feldspar; Cc, calcite; Hb, hornblende; Pr, pyrite; Gs, gypsum; Smt, smectite; III, illite; Chl, chlorite; KIn, kaolinite. sediments measured onboard at Site C0002 (Expedition 315 Scientists 2009; Strasser et al. 2014).

Sample C2571 is a strongly lithified sandstone with angular clastic grains of several tens to several hundred micrometers in size, cemented by calcite (Figure 3c,d). It contains 32 wt $\%$ quartz, $\approx 39$ wt $\%$ feldspar, and $\approx 9$ wt $\%$ hornblende as clastic grains; $\approx 13$ wt $\%$ calcite as the cementing material; and $3.3 \mathrm{wt} \%$ illite and $2.7 \mathrm{wt} \%$ kaolinite as clay minerals (Table 2). The porosity of this sample is as low as $0.7 \%$ due to cementation by calcite.

Sample C2652 is a sandy siltstone (Figure 3b), as described in Takahashi et al. (2013). It contains $\approx 28$ wt $\%$ quartz, $\approx 24$ wt $\%$ feldspar, and $\approx 8$ wt $\%$ hornblende as clastic grains, and $\approx 25 \mathrm{wt} \%$ smectite, $\approx 6 \mathrm{wt} \%$ illite, $\approx 1 \mathrm{wt} \%$ chlorite, and $\approx 2 \mathrm{wt} \%$ kaolinite as clay minerals (Table 2 ). The porosity of this sample is $38.5 \%$, which is within the range of porosity at similar depths measured onboard at Site C0002 (Expedition 315 Scientists 2009).

Sample C9073 is also a sandy siltstone containing grains of a few tens to over $100 \mu \mathrm{m}$ in size, in a clayey matrix (Figure $3 \mathrm{e}$ ). It contains $\approx 32 \mathrm{wt} \%$ quartz and $\approx 32 \mathrm{wt} \%$ feldspar as clastic grains, $\approx 5 \mathrm{wt} \%$ calcite as microfossil grains, and $\approx 22 \mathrm{wt} \%$ smectite, $\approx 5$ wt $\%$ illite, and $\approx 3 \mathrm{wt} \%$ kaolinite as clay minerals (Table 2 ). The porosity of this sample is $29.5 \%$, which is within the range of porosity at similar depths measured onboard at Site C0009 (Expedition 319 Scientists 2010).

Sample C9087 is a fine-grained (mostly $\leq 100 \mu \mathrm{m}$ ) vitric tuff containing some clastic grains (Figure 3f). It contains $\approx 64 \mathrm{wt} \%$ volcanic glass, $\approx 8 \mathrm{wt} \%$ quartz, and $\approx 8 \mathrm{wt} \%$ feldspar as clastic grains, and $\approx 12 \mathrm{wt} \%$ smectite, $\approx 3 \mathrm{wt} \%$ illite, and $\approx 2$ wt $\%$ kaolinite as clay minerals (Table 2 ). The porosity of this sample is $27.4 \%$, which is also within the range of porosity at similar depths measured onboard at Site C0009 (Expedition 319 Scientists 2010).

\section{Experimental results}

We describe below the change in $\mu$, at $V_{\text {axial }}=1 \mu \mathrm{m} / \mathrm{s}$, with $d$. Claystone sample $\mathrm{C} 2516$ exhibited distinct slip weakening after reaching maximum $\mu \approx 0.38$ at $d \approx$ $0.3 \mathrm{~mm}$ until $\mu \approx 0.25$ at $d \approx 2.8 \mathrm{~mm}$ (Figure 4). Sandstone sample $\mathrm{C} 2571$ exhibited slip hardening after reaching $\mu \approx 0.80$ at $d \approx 0.75 \mathrm{~mm}$ until $\mu \approx 0.87$ at $d \approx 3.4 \mathrm{~mm}$ (Figure 4). Siltstone sample C2652 exhibited slight slip weakening after reaching maximum $\mu \approx 0.56$ at $d \approx$ $0.7 \mathrm{~mm}$ until $\mu \approx 0.53$ at $d \approx 3.2 \mathrm{~mm}$ (Figure 4 ). Another siltstone sample, C9073, exhibited quasi steady-state slip after reaching $\mu \approx 0.56$ at $d \approx 0.7 \mathrm{~mm}$ (Figure 4). Tuff sample C9087 also exhibited quasi steady-state slip after reaching $\mu \approx 0.71$ at $d \approx 1.15 \mathrm{~mm}$ (Figure 4 ).

All samples exhibited velocity-strengthening behavior as shown by an increase in $\mu$ when $V_{\text {axial }}$ was increased, and vice versa (Figure 4). The difference between the decayed friction levels before and after a stepwise change 


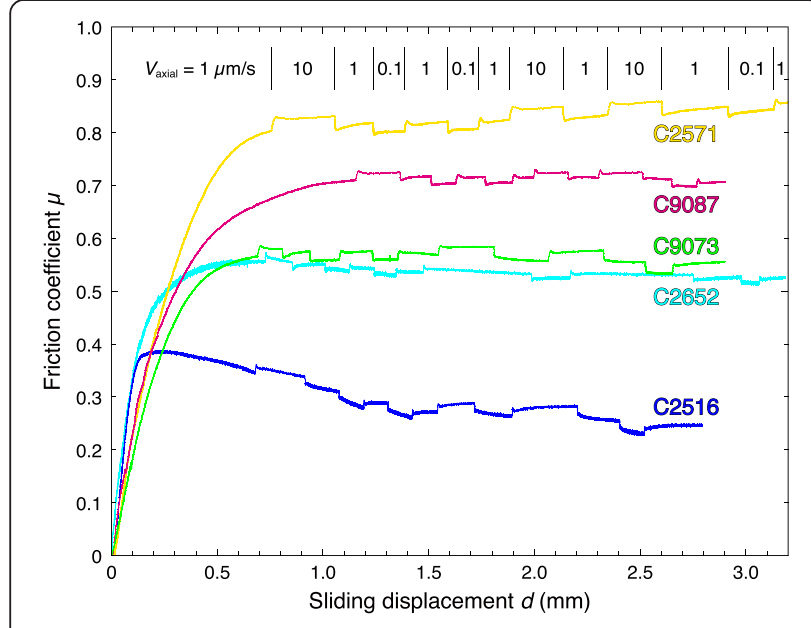

Figure 4 Friction coefficient $\mu$ plotted against sliding displacement $d$ for gouges of five samples tested in this study. The sequence of steps in axial displacement rate $\left(V_{\text {axial }}\right)$ is shown only for sandstone sample 2571, but the same sequence was applied to all the other samples. See Table 3 for experimental conditions. in $V_{\text {axial }}$ is largest for the sandstone sample, C2571, while it is the smallest for the siltstone sample, C2652 (Figure 4). As already described in Takahashi et al. (2013), claystone sample C2516 exhibited an asymptotic change in $\mu$ following instantaneous and decayed responses after a stepwise change in $V_{\text {axial }}$ (Figure 4). Such frictional behavior had also been observed during friction experiments on serpentinite (Reinen et al. 1991; Takahashi et al. 2011) and has been ascribed to a flow component during frictional sliding (Takahashi et al. 2011, 2013).

We fit the observed friction data with the mixed friction-flow law proposed by Takahashi et al. (2011, 2013). At each velocity step after $d=1.5 \mathrm{~mm}$, we determined the parameter $(a-b)$ defined by the rate- and state-dependent friction constitutive law (Dieterich 1979, 1981) (Figure 5) and the steady-state friction coefficient $\left(\mu_{\mathrm{ss}}\right)$ after the flow response (Figure 6) (cf. inset in Figure 5). We used friction data after $d=1.5 \mathrm{~mm}$ in order to avoid the effects of slip hardening or weakening and picked only data for which fitting was successful. The $(a-b)$ values are positive for all samples, ranging from 0.0004 to 0.0107 (Figure 5). The $(a-b)$

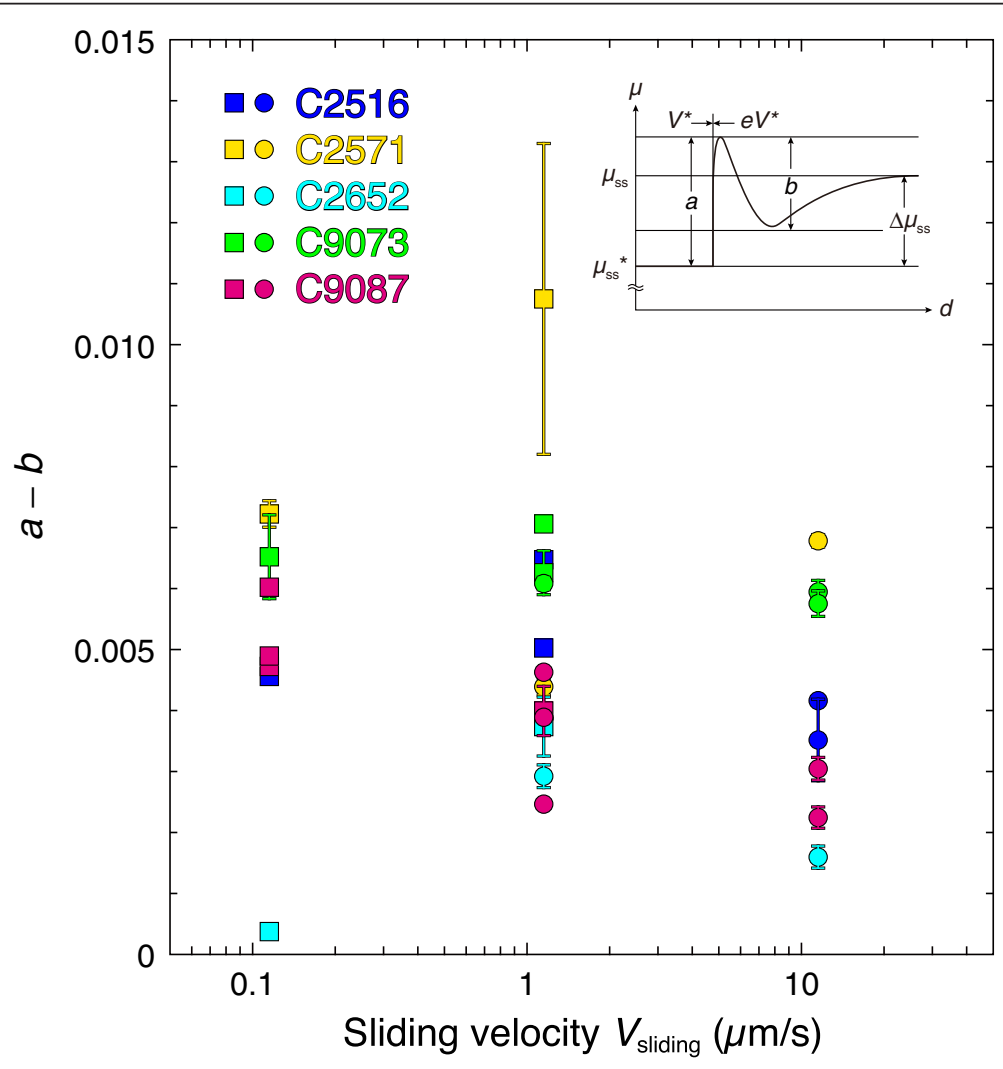

Figure 5 Values of $(\boldsymbol{a}-\boldsymbol{b})$ plotted against sliding velocity $V_{\text {sliding }}$ for the five samples tested in this study. Vertical bars indicate error bars. Squares are $(a-b)$ values after stepping down in $V_{\text {sliding, }}$ while circles are those values after stepping up in $V_{\text {sliding. The inset illustrates the mixed }}$ friction-flow law of Takahashi et al. $(2011,2013)$, where the steady-state friction coefficient $\left(\mu_{\mathrm{ss}}\right)$ after a stepwise change in $V_{\text {sliding }}$ from $V^{*}$ to $\mathrm{eV}^{*}$ is reached after a flow response following the direct and evolutionary effects ( $a$ and $b$ ). $d$, displacement; $\mu$, friction coefficient; $\mu_{\mathrm{ss}}{ }^{*}$, steady-state friction coefficient at $V^{*} ; \Delta \mu_{\mathrm{ss}}$ difference between $\mu_{\mathrm{ss}}$ and $\mu_{\mathrm{ss}}{ }^{*}$. 


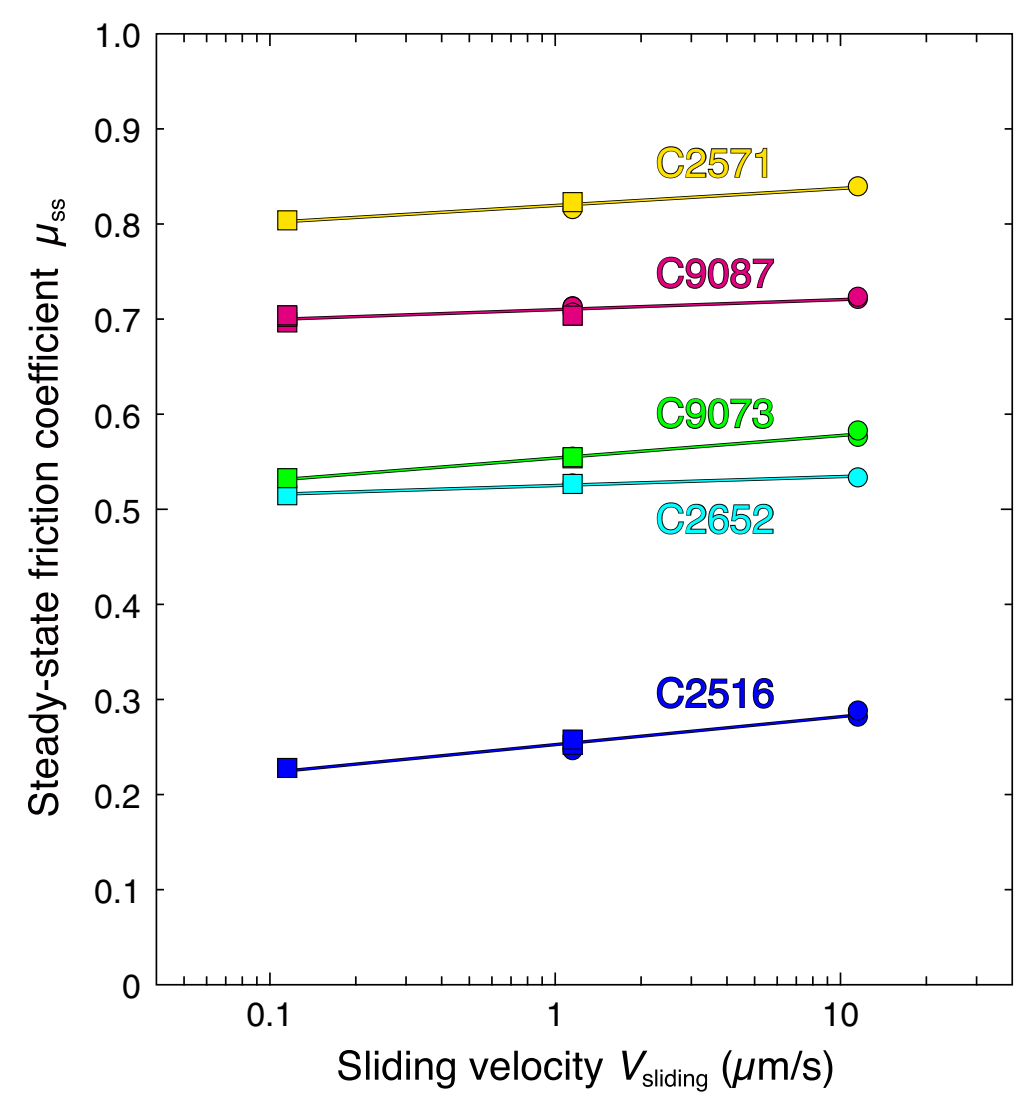

Figure 6 Steady-state friction coefficient $\mu_{\mathrm{ss}}$ plotted against sliding velocity $V_{\text {sliding }}$ for the five samples tested in this study. Least-squares fitted lines are also shown. Squares are $\mu_{\text {ss }}$ values after stepping down in $V_{\text {sliding, }}$ while circles are those values after stepping up in $V_{\text {sliding. }}$.

values of each sample tend to decrease with increasing $V_{\text {sliding }}$ (Figure 5). At each $V_{\text {sliding }}$, the $(a-b)$ values of sandstone sample C2571 and siltstone sample C9073 are relatively large, while those of siltstone sample C2652 and tuff sample C9087 are relatively small (Figure 5). Average and standard deviation $(a-b)$ values for each sample are shown in Table 3 . The $\mu_{\mathrm{ss}}$ values increase linearly with increasing logarithmic $V_{\text {sliding }}$ for all samples (Figure 6). The least-squares line fitting of these data gives the ratio of incremental $\mu_{\mathrm{ss}}$ to incremental logarithmic $V_{\text {sliding }}\left(\Delta \mu_{\mathrm{ss}} / \Delta \ln V_{\text {sliding }}\right)$, i.e., the velocity dependence of steady-state friction. The $\Delta \mu_{\mathrm{ss}} l$
$\Delta \ln V_{\text {sliding }}$ value and its error for each sample are also shown in Table 3. The $\Delta \mu_{\mathrm{ss}} / \Delta \ln V_{\text {sliding }}$ value ranges from 0.0041 to 0.0127 (Table 3). The $\Delta \mu_{\mathrm{ss}} / \Delta \ln V_{\text {sliding values of }}$ claystone sample C2516 and siltstone sample C9073 are relatively large, while those of siltstone sample C2652 and tuff sample C9087 are relatively small (Table 3; Figure 6).

The $\mu_{\mathrm{ss}}$ at $V_{\text {axial }}=1 \mu \mathrm{m} / \mathrm{s}$ for each sample is obtained by inputting the corresponding $V_{\text {sliding }}$ value $(1.155 \mu \mathrm{m} / \mathrm{s})$ to the equation of the least-squares fitted line shown in Figure 6 (Table 3). The $\mu_{\mathrm{ss}}$ at $V_{\text {axial }}=1 \mu \mathrm{m} / \mathrm{s}$ differs according to lithology; sandstone sample $\mathrm{C} 2571$ has the highest $\mu_{\mathrm{ss}}$ of 0.82 , tuff sample C9087 has the second highest $\mu_{\mathrm{ss}}$

Table 3 Summary of experimental conditions and results

\begin{tabular}{lcccccccc}
\hline Sample & $\boldsymbol{T}$ & $\boldsymbol{P}_{\mathbf{c}}(\mathbf{M P a})$ & $\boldsymbol{P}_{\mathbf{p}}(\mathbf{M P a})$ & $\boldsymbol{V}_{\text {axial }}(\boldsymbol{\mu m} / \mathbf{s})$ & $\boldsymbol{V}_{\text {sliding }}(\boldsymbol{\mu \mathrm { m } / \mathbf { s } )}$ & $\boldsymbol{\mu}_{\mathbf{s s}} @ V_{\text {axial }}=\mathbf{1} \boldsymbol{\mu \mathrm { m } / \mathbf { s }}$ & $\boldsymbol{a}-\boldsymbol{b}$ & $\Delta \boldsymbol{\mu}_{\mathbf{s s}} / \Delta \mathbf{l n} \boldsymbol{V}_{\text {sliding }}$ \\
\hline C2516 & RT & 36 & 28 & $0.1,1,10$ & $0.1155,1.155,11.55$ & 0.25 & $0.0046 \pm 0.0011$ & $0.0127 \pm 0.0013$ \\
C2571 & RT & 37 & 29 & $0.1,1,10$ & $0.1155,1.155,11.55$ & 0.82 & $0.0073 \pm 0.0026$ & $0.0078 \pm 0.0012$ \\
C2652 & RT & 38 & 29 & $0.1,1,10$ & $0.1155,1.155,11.55$ & 0.53 & $0.0022 \pm 0.0015$ & $0.0041 \pm 0.0006$ \\
C9073 & RT & 57 & 43 & $0.1,1,10$ & $0.1155,1.155,11.55$ & 0.56 & $0.0063 \pm 0.0005$ & $0.0103 \pm 0.0007$ \\
C9087 & RT & 57 & 43 & $0.1,1,10$ & $0.1155,1.155,11.55$ & 0.71 & $0.0040 \pm 0.0012$ & $0.0046 \pm 0.0017$ \\
\hline
\end{tabular}

$T$, temperature; RT, room temperature; $P_{\mathrm{c}}$ confining pressure; $P_{\mathrm{p}}$, pore pressure; $V_{\text {axial, }}$ axial displacement rate; $V_{\text {sliding, }}$ sliding velocity; $\mu_{\mathrm{ss}}$ steady-state friction coefficient; $a-b$, difference in instantaneous and decayed responses after an $e$-times stepwise change in sliding velocity; $\Delta \mu_{\text {ss }} / \Delta \mathrm{ln} V_{\text {sliding, }}$ ratio of incremental steady-state friction coefficient to incremental logarithmic sliding velocity. See text for details to determine $\mu_{\mathrm{ss}}(a-b)$, and $\Delta \mu_{\mathrm{ss}} / \Delta \ln V_{\mathrm{sliding}}$ values. 
of 0.71, siltstone samples C2652 and C9073 have similar $\mu_{\mathrm{ss}}$ of $\approx 0.55$, and claystone sample C2512 has the lowest $\mu_{\mathrm{ss}}$ of 0.25 (Table 3; Figure 7).

\section{Discussion}

Our triaxial friction experiments revealed that samples of different lithologies are not only different in steadystate frictional strength, but also in slip-dependent frictional behavior (Figures 4 and 7; Table 3). These differences in frictional strength and behavior according to lithology are attributable to their different clay mineral contents, in particular, their smectite contents, as discussed below. The content of clay minerals differs according to lithology; it is $6 \mathrm{wt} \%$ in sandstone sample C2571, $\approx 17 \mathrm{wt} \%$ in tuff sample C9087, 29 to $34 \mathrm{wt} \%$ in siltstone samples $\mathrm{C} 2652$ and C9073, and $42 \mathrm{wt} \%$ in claystone sample C2516 (Table 2). Except for sandstone sample C2571, in which smectite is absent, smectite is the most abundant clay mineral in the samples, comprising 68 to $76 \mathrm{wt} \%$ of the total clay minerals (Table 2).

Previous friction experiments on gouges of synthetic quartz-clay mixtures revealed that frictional strength decreases with increasing clay content (e.g., Lupini et al. 1981; Rutter et al. 1986; Logan and Rauenzahn 1987; Saffer and Marone 2003; Ikari et al. 2007; Takahashi et al. 2007; Crawford et al. 2008; Tembe et al. 2010;
Moore and Lockner 2011). The steady-state friction coefficient $\left(\mu_{\mathrm{ss}}\right)$ of our accretionary sediment gouges at $V_{\text {axial }}=$ $1 \mu \mathrm{m} / \mathrm{s}$ also decreases with increasing content of smectite or clay minerals (Figure 7). The $\mu_{\mathrm{ss}}$ at $V_{\text {axial }}=1 \mu \mathrm{m} / \mathrm{s}$ decreases linearly from 0.82 for sandstone sample C2571 with $0 \mathrm{wt} \%$ smectite and $6 \mathrm{wt} \%$ clay minerals to 0.53 for siltstone sample $\mathrm{C} 2652$ with $\approx 25 \mathrm{wt} \%$ smectite and $\approx 34 \mathrm{wt} \%$ clay minerals (Figure 7 ). However, the $\mu_{\mathrm{ss}}$ of claystone sample C2516, with 32 wt\% smectite and $42 \mathrm{wt} \%$ clay minerals, is 0.25 , significantly lower than this linear decreasing trend (Figure 7). Takahashi et al. (2007), Tembe et al. (2010), and Moore and Lockner (2011) also reported a linear decreasing trend of frictional strength up to a certain amount of clay minerals, and a drop from the linear trend for larger amounts of clay minerals. This change in rate of strength decrease has been attributed to a change in the load-bearing framework, from quartzsupported to matrix-supported (e.g., Tembe et al. 2010), which occurs at variable clay mineral contents according to experimental conditions, i.e., $\approx 45 \mathrm{wt} \%$ in the experiments of Takahashi et al. (2007) and $\approx 15$ wt\% in the experiments of Tembe et al. (2010) and Moore and Lockner (2011). Such change likely occurred in our experiments at $\approx 30 \mathrm{wt} \%$ of smectite and $\approx 40 \mathrm{wt} \%$ of clay minerals.

Slip-dependent frictional behavior also changes systematically according to the content of smectite or clay

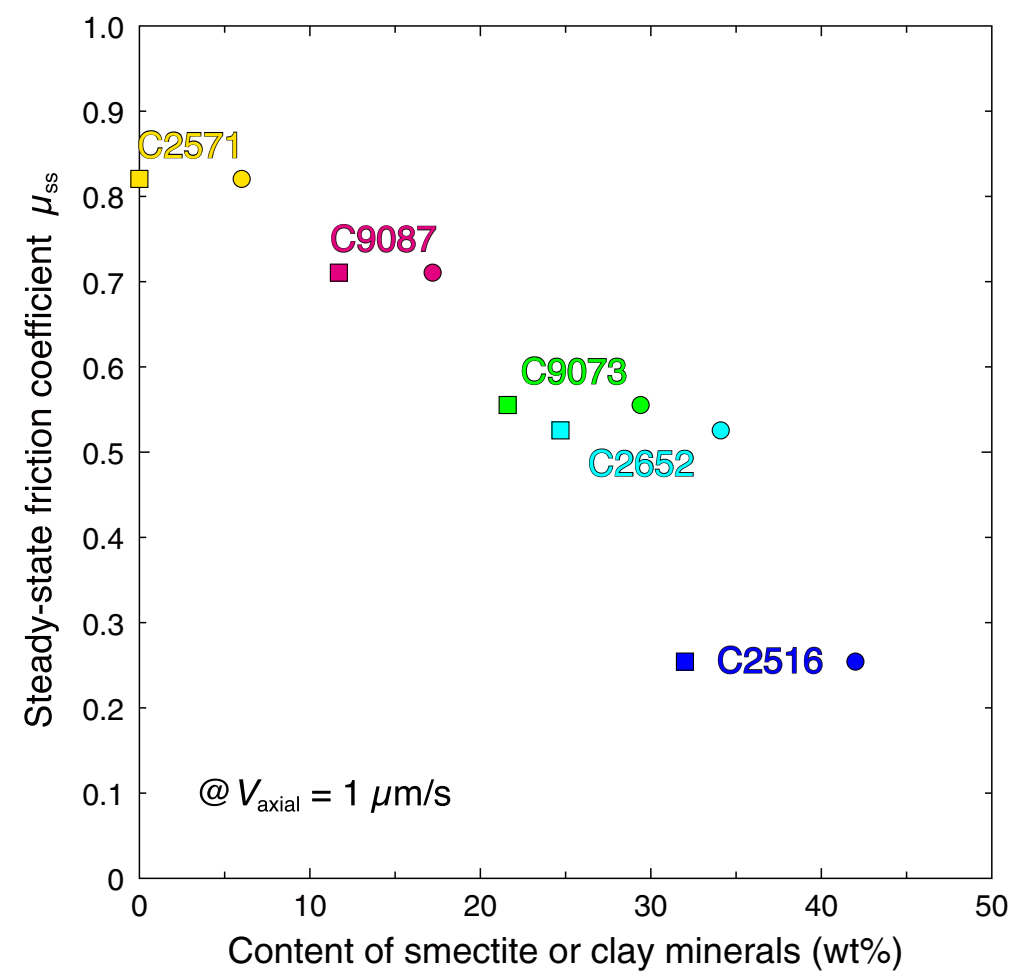

Figure $7 \mu_{\mathrm{ss}}$ plotted against smectite/clay-mineral content for the five samples tested in this study. Steady-state friction coefficient $\mu_{\mathrm{ss}}$ at an axial displacement rate $\left(V_{\text {axial }}\right)$ of $1 \mu \mathrm{m} / \mathrm{s}$ is plotted against the content of smectite (squares) or clay minerals (circles). Values of $\mu_{\mathrm{ss}}$ are obtained by inputting the corresponding $V_{\text {sliding }}$ value in the equations of the least-squares fitted lines shown in Figure 6. 
minerals, from slip hardening of sandstone sample C2571, through quasi steady-state slip of tuff sample C9087 and siltstone sample C9073, to slight slip weakening of siltstone sample C2652 and distinct slip weakening of claystone sample C2516 (Figure 4). Such systematic change in slip-dependent frictional behavior according to the content of clay minerals is also consistent with the results of previous studies (e.g., Saffer and Marone 2003; Moore and Lockner 2011). It should be noted, however, that slip-dependent frictional behavior is only transient until a steady-state is reached. Clay-poor gouge samples likely experienced substantial grain-size reduction and compaction, resulting in slip hardening (e.g., Morrow and Byerlee 1989). In contrast, in clay-rich gouge samples, initial compaction hardening was likely followed by weakening due to preferred alignment of clay minerals along shear planes (e.g., Moore and Lockner 2004).

Except for siltstone sample C2652 and tuff sample C9087, whose $(a-b)$ and $\Delta \mu_{\mathrm{ss}} / \Delta \ln V_{\text {sliding }}$ values are smaller than those of the other samples, there is a tendency for the $(a-b)$ value to decrease while the $\Delta \mu_{\mathrm{ss}} /$ $\Delta \ln V_{\text {sliding }}$ value increases with increasing clay mineral content (Figure 8). Thus, the difference between the $(a-b)$ and $\Delta \mu_{\mathrm{ss}} / \Delta \ln V_{\text {sliding }}$ values increases with increasing clay mineral content, which is also true for the above two exceptional samples (Figure 8). It is unknown at present why these two samples show exceptionally small $(a-b)$ and $\Delta \mu_{\mathrm{ss}} / \Delta \ln V_{\text {sliding }}$ values, but when we plot the ratio of $(a-b)$ to $\Delta \mu_{\mathrm{ss}} / \Delta \ln V_{\text {sliding }}$ against the content of smectite or clay minerals, it is evident that the ratio decreases with increasing content of smectite or clay minerals (Figure 9). This implies that the contribution of $(a-b)$ defined by the rate- and state-dependent friction constitutive law (Dieterich 1979, 1981) becomes smaller in velocity dependence of steady-state friction as the content of smectite or clay minerals increases. In other words, the friction component in frictional sliding decreases while the flow component increases with increasing clay mineral content ( $c f$., Takahashi et al. 2013). In the case of sandstone sample C2571, the ratio of $(a-b)$ to $\Delta \mu_{\text {ss }} / \Delta \ln V_{\text {sliding }}$ is $\approx 0.94$ (Figure 9), so that the frictional sliding of this sample is mostly composed of friction. In contrast, in the case of claystone sample C2516, the ratio of $(a-b)$ to $\Delta \mu_{\mathrm{ss}} / \Delta \ln V_{\text {sliding }}$ is $\approx 0.36$ (Figure 9), so that the frictional sliding of this sample is composed mainly of flow. This must be due to the abundance of clay minerals (42 wt\%), in particular of smectite (32 wt\%), in this sample (Table 2). Thus, our results show that the rate- and statedependent friction constitutive law alone cannot sufficiently describe the friction characteristics of materials containing a certain amount of clay minerals, in particular smectite.

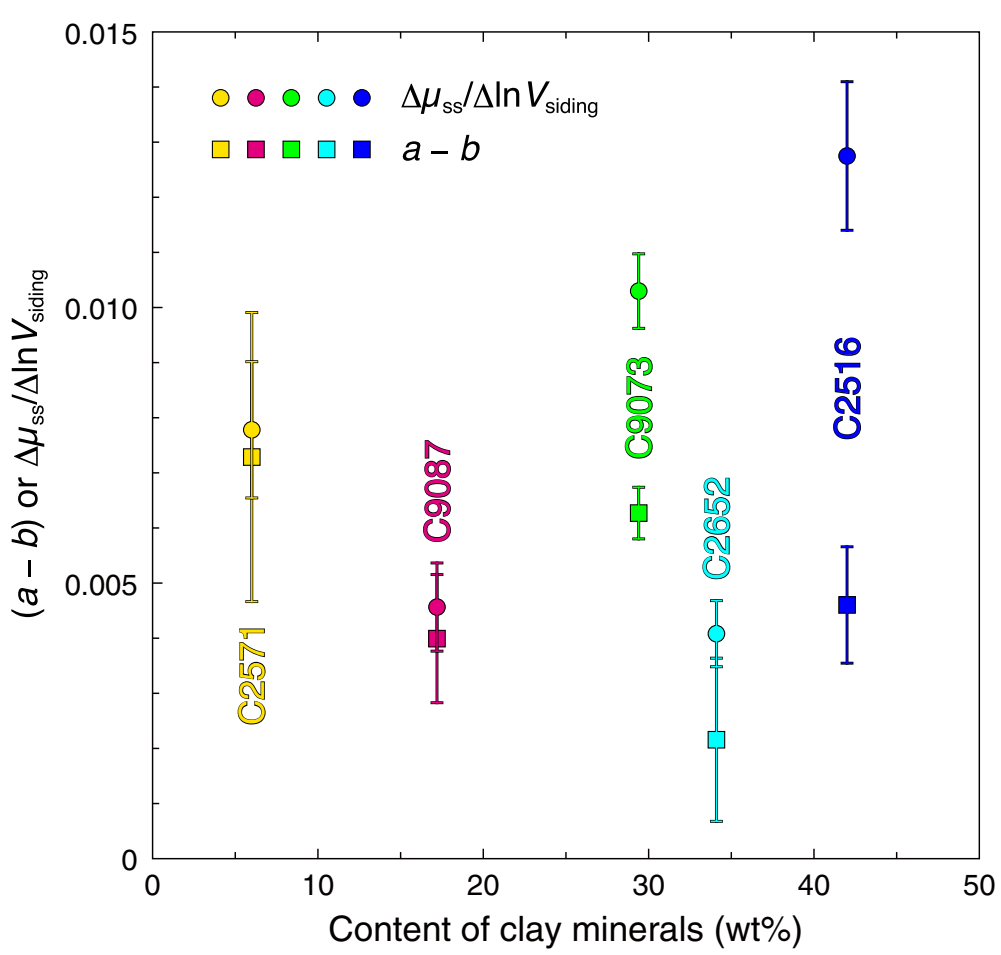

Figure $8(\boldsymbol{a}-\boldsymbol{b})$ or $\left(\Delta \mu_{\mathrm{ss}} / \Delta \ln V_{\text {sliding }}\right)$ plotted against clay-mineral content for the five samples tested in this study. Values of $(a-b)$ (squares) and ratios of incremental steady-state friction coefficient to incremental logarithmic sliding velocity $\left(\Delta \mu_{\mathrm{ss}} / \Delta \ln V_{\text {sliding }}\right)$ (circles) are plotted against the content of clay minerals. Squares with vertical bars indicate average and standard deviation values of $(a-b)$ values plotted in Figure 5 , while circles with vertical bars indicate $\Delta \mu_{s s} / \Delta \ln V_{\text {sliding }}$ values and their errors from the least-squares fit shown in Figure 6. 


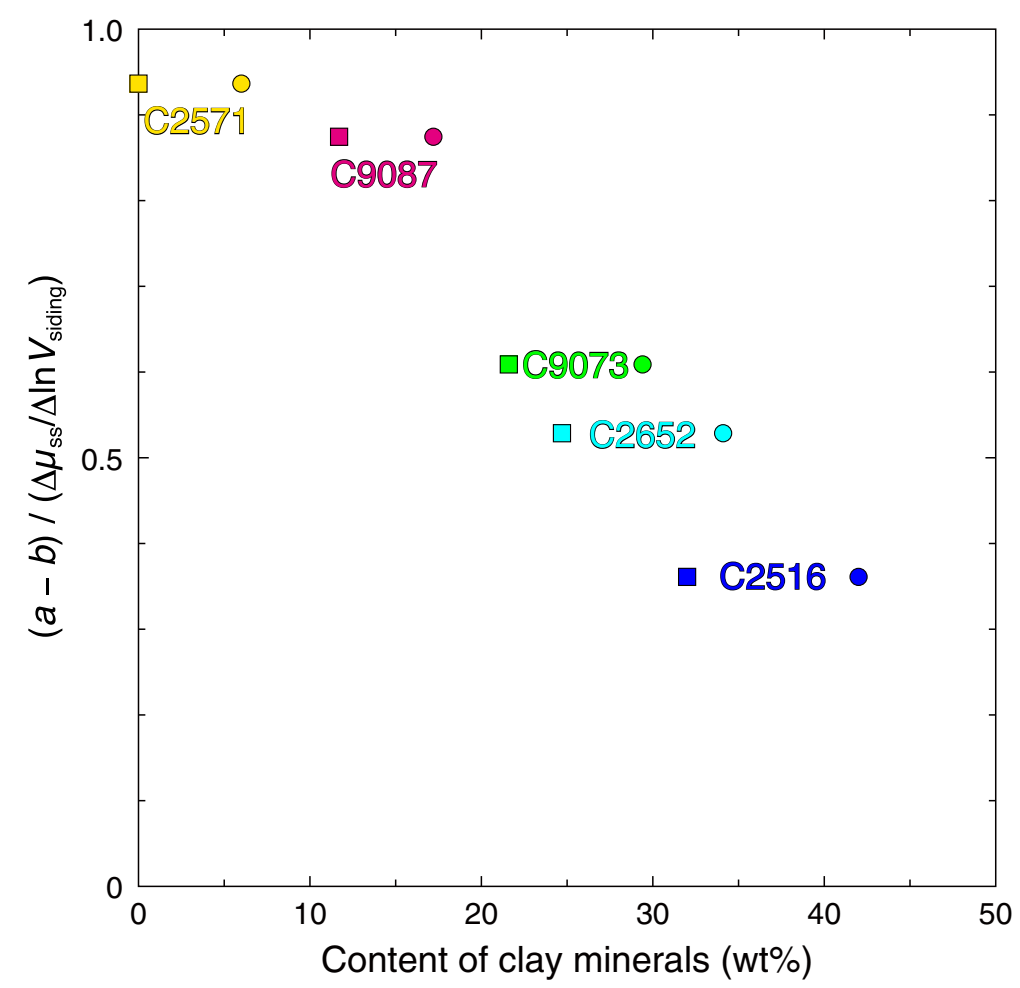

Figure $9(a-b) /\left(\Delta \mu_{s s} / \Delta \ln V_{\text {sliding }}\right)$ plotted against smectite/clay-mineral content for the five samples tested in this study. Values of $(a-b)$ relative to ratio of incremental steady-state friction coefficient to incremental logarithmic sliding velocity $\left(\Delta \mu_{s s} / \Delta \ln V_{\text {sliding }}\right)$ are plotted against the content of smectite (squares) or clay minerals (circles).

Friction experiments on mudstone (siltstone and claystone) samples cored at Sites C0004 and C0007 (Figure 1) during IODP Expedition 316 have also been conducted by Hirose et al. (2008), Ikari et al. (2009, 2013), Ujiie and Tsutsumi (2010), Ikari and Saffer (2011), and Tsutsumi et al. (2011). These studies reported $\mu_{\mathrm{ss}}$ of 0.25 to 0.54 and positive $(a-b)$ values with a few negative exceptions at $V_{\text {sliding }} \leq 1 \mathrm{~mm} / \mathrm{s}$, which are generally consistent with our results for the siltstone and claystone samples. Ikari and Saffer (2011) reported a dependence of $(a-b)$ values on $V_{\text {sliding, }}$ such that they decrease with increasing $V_{\text {sliding }}$ up to $3 \mu \mathrm{m} / \mathrm{s}$ and then increase for faster $V_{\text {sliding }}$ up to $100 \mu \mathrm{m} / \mathrm{s}$, which is similar to our results of $(a-b)$ values decreasing with increasing $V_{\text {sliding }}$ up to $11.55 \mu \mathrm{m} / \mathrm{s}$ (Figure 5). They showed that $b$ values have an opposite trend to that of $(a-b)$ values, which we see only for a few samples in our experiments. Ikari et al. (2013) also reported that slip-weakening behavior was common for their samples at $V_{\text {sliding }}=0.1$ to $10 \mu \mathrm{m} / \mathrm{s}$, which is also consistent with our result for the claystone sample. However, these studies do not take account of the flow component during their experiments, induced by the presence of clay minerals supposed to be abundant in their samples. Consequently, the velocity dependence of steady-state friction $\left(\Delta \mu_{\mathrm{ss}} / \Delta \ln V_{\text {sliding }}\right)$ was likely underestimated in these studies.

Takahashi et al. (2013) reported, from triaxial compression experiments on claystone sample C2512 and siltstone sample C2652, that the former is weaker than the latter and fails slowly. In addition to its intrinsic weakness due to the abundance of clay minerals, the low porosity and permeability of the claystone sample likely resulted in an increase in pore pressure during its compression, which may have further weakened this sample and promoted its slow failure (Takahashi et al. 2013). It has recently been suggested that the slow slip events or very low frequency earthquakes observed within the Nankai Trough accretionary prism or along the shallow décollement (Ito and Obara 2006; Sugioka et al. 2012) occur in regions of elevated pore fluid pressures (Park et al. 2010; Kitajima and Saffer 2012). Because claystone is likely under a high pore water pressure during its compression, and also because it fails slowly, faulting in claystone layers is a possible source for such slow slip events or very low frequency earthquakes. A significant flow component during the frictional sliding of claystone also favors slow slip. In addition, Ikari et al. (2013) suggested that millimeter-scale slip-weakening behavior at 
$V_{\text {sliding }}=0.1$ to $10 \mu \mathrm{m} / \mathrm{s}$, as observed for the claystone sample in this study, may generate slow earthquakes, which also supports the above hypothesis.

\section{Conclusions}

Our triaxial friction experiments on samples of different lithologies reveal that the frictional properties of the shallow Nankai Trough accretionary sediments change systematically according to the clay mineral content, in particular the smectite content. With increasing clay mineral content, frictional strength decreases, and slipdependent frictional behavior changes from slip hardening, through quasi steady-state slip, to slip weakening. Although velocity-strengthening behavior is commonly observed, the friction component in frictional sliding decreases while the flow component increases with increasing clay mineral content. The velocity dependence of friction generally becomes more positive, so that faulting becomes accordingly more stable. Thus, faulting in the shallow Nankai Trough accretionary prism is likely controlled by the content of clay minerals, in particular of smectite, in the sediments as well as in the fault zones. Together with the results of triaxial compression experiments we reported earlier, our results suggest that faulting in claystone layers is a possible source for slow slip events or very low frequency earthquakes observed in the shallow Nankai Trough accretionary prism or along the shallow décollement.

\section{Competing interests}

The authors declare that they have no competing interests.

\section{Authors' contributions}

KK obtained the samples and planned the experiments. MT, SA, and HI conducted the experiments, and MT analyzed the results. SA, HI, and Al conducted the XRD analyses, and SA, HI, and KK conducted the porosity measurements. KK drafted the manuscript, and all authors read and approved the final manuscript.

\section{Acknowledgements}

We used samples and data provided by the Integrated Ocean Drilling Program (IODP). KK thanks the operation staff of DN Chikyu and the onboard laboratory technicians of Marine Works Japan for their support. We also thank M. Shimogawara and H. Kaito for assisting with porosity measurements, S. Uehara for assisting with experiments, Y. Nakamura for providing the composite seismic profile used in Figure $1 \mathrm{~b}$, KANAME members for discussions, three anonymous reviewers for helpful reviews, and G. Kimura for editorial handling. This study was supported by a MEXT KANAME grant \#21107004 to MT and KK.

\section{Author details \\ ${ }^{1}$ Institute of Earthquake and Volcano Geology, Geological Survey of Japan, Tsukuba 305-8567, Japan. ²Department of Earth Sciences, Chiba University, Chiba 263-8522, Japan. ${ }^{3}$ Present address: SK Engineering, Co., Ltd, Tokyo 101-0032, Japan.}

Received: 2 December 2013 Accepted: 30 June 2014 Published: 23 July 2014

\section{References}

Ando M (1975) Source mechanisms and tectonic significance of historical earthquakes along the Nankai Trough, Japan. Tectonophys 27:119-140
Ashi J, Lallemant S, Masago H Expedition 315 Scientists (2009) Expedition 315 summary. In: Kinoshita M, Tobin H, Ashi J, Kimura G, Lallemant S, Screaton EJ, Curewitz D, Masago H, Moe KT (eds) Expedition 314/315/316 Scientists, Proc IODP 314/315/316. IODP MI, Washington DC, doi:10.2204/iodp.proc. 314315316.121 .2009

Chung FH (1974) Quantitative interpretation of X-ray diffraction patterns I. Matrix-flushing method of quantitative multicomponent analysis. J Appl Crystal 7:519-525

Crawford BR, Faulkner DR, Rutter EH (2008) Strength, porosity, and permeability development during hydrostatic and shear loading of synthetic quartz-clay fault gouge. J Geophys Res 113, B03207, doi:10.1029/2006JB004634

Dieterich JH (1979) Modeling of rock friction. 1. Experimental results and constitutive equations. J Geophys Res 84:2161-2168

Dieterich JH (1981) Constitutive properties of faults with simulated gouge. In: Carter NL, Friedman M, Logan JM, Stearns DW (eds) Mechanical Behavior of Crustal Rocks, vol 24. Geophys Monogr., American Geophysical Union, Washington DC, pp 103-120

Expedition 315 Scientists (2009) Expedition 315 Site C0002. In: Kinoshita M, Tobin H, Ashi J, Kimura G, Lallemant S, Screaton EJ, Curewitz D, Masago H, Moe KT (eds) Expedition 314/315/316 Scientists, Proc IODP 314/315/316. IODP MI, Washington DC, doi:10.2204/iodp.proc.314315316.124.2009

Expedition 319 Scientists (2010) Site C0009. In: Saffer D, McNeill L, Byrne T, Araki E, Toczko S, Eguchi N, Takahashi K (eds) Expedition 319 Scientists, Proc IODP 319. IODP MI, Tokyo, doi:10.2204/iodp.proc.319.103.2010

Expedition 333 Scientists (2012) Expedition 333 summary. In: Henry P, Kanamatsu T, Moe KT (eds) Expedition 333 Scientists, Proc IODP 333. IODP MI, Tokyo, doi:10.2204/iodp.proc.333.101.2012

Heki K (2007) Secular, transient and seasonal crustal movements in Japan from a dense GPS array: implication for plate dynamics in convergent boundaries. In: Dixon TH, Moore JC (eds) The Seismogenic Zone of Subduction Thrust Faults. Columbia University Press, New York, pp 512-539

Hirose T, Tanikawa W, Sakaguchi M, Tadai O, Lin W, Scientific P (2008) High-velocity frictional behavior of clay-rich sediments from IODP Expedition 316, Nankai Trough, offshore Japan. Fall Meeting, American Geophysical Union, Washington DC, pp T31A-1980

Hori T, Kato N, Hirahara K, Baba T, Kaneda Y (2004) A numerical simulation of earthquake cycles along the Nankai Trough in southwest Japan: lateral variation in frictional property due to the slab geometry controls the nucleation position. Earth Planet Sci Lett 228:215-226

Ikari MJ, Saffer DM (2011) Comparison of frictional strength and velocity dependence between fault zones in the Nankai accretionary complex. Geochem Geophys Geosys 12:Q0AD11, doi:10.1029/2010GC003442

Ikari MJ, Saffer DM, Marone C (2007) Effect of hydration state on the frictional properties of montmorillonite-based fault gouge. J Geophys Res 112, B06423, doi:10.1029/2006JB004748

Ikari MJ, Saffer DM, Marone C (2009) Frictional and hydrologic properties of a major splay fault system, Nankai subduction zone. Geophys Res Lett 36, L20313, doi:10.1029/2009GL040009

Ikari MJ, Marone C, Saffer DM, Kopf AJ (2013) Slip weakening as a mechanism for slow earthquakes. Nature Geosci 6:468-472

Ito $Y$, Obara K (2006) Dynamic deformation of the accretionary prism excites very low frequency earthquakes. Geophys Res Lett 33, L02311, doi:10.1029/2005GL025270

Kikuchi M, Nakamura M, Yoshikawa K (2003) Source rupture processes of the 1944 Tonankai earthquake and the 1945 Mikawa earthquake derived from low-gain seismograms. Earth Planets Space 55:159-172

Kitajima H, Saffer DM (2012) Elevated pore pressure and anomalously low stress in regions of low frequency earthquakes along the Nankai Trough subduction megathrust. Geophys Res Lett 39, L23301, doi:10.1029/ 2012GL053793

Logan JM, Rauenzahn KA (1987) Frictional dependence of gouge mixtures of quartz and montmorillonite on velocity, composition and fabric. Tectonophys 144:87-108

Lupini JF, Skinner AE, Vaughan PR (1981) The drained residual strength of cohesive soils. Géotechnique 31:181-213

Masuda K, Fujimoto K, Arai T (2002) A new gas-medium, high-pressure and high-temperature deformation apparatus at AIST, Japan. Earth Planets Space 54:1091-1094

Moore DE, Lockner DL (2004) Crystallographic controls on the frictional behavior of dry and water-saturated sheet structure minerals. J Geophys Res 109 B03401, doi:10.1029/2003JB002582 
Moore DE, Lockner DL (2011) Frictional strengths of talc-serpentine and talc-quartz mixtures. J Geophys Res 116, B01403, doi:10.1029/2010JB007881

Moore GF, Bangs NL, Taira A, Kuramoto S, Pangborn E, Tobin HJ (2007) Three-dimensional splay fault geometry and implications for tsunami generation. Science 318:1128-1131

Morrow CA, Byerlee JD (1989) Experimental studies of compaction and dilatancy during frictional sliding on faults containing gouge. J Struct Geol 11:815-825

Nakano M, Nakamura T, Kamiya S, Ohori M, Kaneda Y (2013) Intensive seismic activity around the Nankai trough revealed by DONET ocean-floor seismic observations. Earth Planets Space 65:5-15

Park JO, Kodaira S (2012) Seismic reflection and bathymetric evidences for the Nankai earthquake rupture across a stable segment-boundary. Earth Planets Space 64:299-303

Park JO, Tsuru T, Kodaira S, Cummins PR, Kaneda Y (2002) Splay fault branching along the Nankai subduction zone. Science 297:1157-1160

Park JO, Fujie G, Wijerathne L, Hori T, Kodaira S, Fukao Y, Moore GF, Bangs NL, Kuramoto S, Taira A (2010) A low-velocity zone with weak reflectivity along the Nankai subduction zone. Geology 38:283-286

Reinen LA, Weeks JD, Tullis TE (1991) The frictional behavior of serpentinite: implications for aseismic creep on shallow crustal faults. Geophys Res Lett 18:1921-1924

Rutter EH, Maddock RH, Hall SH, White SH (1986) Comparative microstructures of natural and experimentally produced clay-bearing fault gouges. Pure Appl Geophys 124:3-30

Saffer DM, Marone C (2003) Comparison of smectite- and illite-rich gouge frictional properties: application to the updip limit of the seismogenic zone along subduction megathrusts. Earth Planet Sci Lett 215:219-235

Sakaguchi A, Kimura G, Strasser M, Screaton EJ, Curewitz D, Murayama M (2011) Episodic seafloor mud brecciation due to great subduction zone earthquakes. Geology 39:919-922

Screaton EJ, Kimura G, Curewitz D, Expedition 316 Scientists (2009) Expedition 316 summary. In: Kinoshita M, Tobin H, Ashi J, Kimura G, Lallemant S, Screaton EJ, Curewitz D, Masago H, Moe KT (eds) Expedition 314/315/316 Scientists, Proc IODP 314/315/316. IODP MI, Washington DC, doi:10.2204/ iodp.proc.314315316.131.2009

Seno T, Stein S, Gripp AE (1993) A model for the motion of the Philippine Sea plate consistent with NUVEL-1 and geological data. J Geophys Res 98:17941-17948

Strasser M, Dugan B, Kanagawa K, Moore GF, Toczko S, Maeda L, Kido Y, Moe KT, Sanada Y, Esteban L, Fabbri O, Geersen J, Hammerschmidt S, Hayashi H, Heirman K, Hüpers A, Jurado Rodriguez MJ, Kameo K, Kanamatsu T, Kitajima H, Masuda H, Milliken K, Mishra R, Motoyama I, Olcott K, Oohashi K, Pickering KT, Ramirez SG, Rashid H, Sawyer D et al (2014) Site C0002. In: Strasser M, Dugan B, Kanagawa K, Moore GF, Toczko S, Maeda L (eds) Expedition 338 Scientists, Proc IODP 338. IODP, Yokohama, doi:10.2204/iodp.proc.338.103.2014

Sugioka H, Okamoto T, Nakamura T, Ishihara Y, Ito A, Obana K, Kinoshita M, Nakahigashi K, Shinohara M, Fukao Y (2012) Tsunamigenic potential of the shallow subduction plate boundary inferred from slow seismic slip. Nature Geosci 5:414-418

Takahashi M, Mizoguchi K, Kitamura K, Masuda K (2007) Effects of clay content on the frictional strength and fluid transport property of faults. J Geophys Res 112, B08206, doi:10.1029/2006JB004678

Takahashi M, Uehara S, Mizoguchi K, Shimizu I, Okazaki K, Masuda K (2011) On the transient response of serpentine (antigorite) gouge to stepwise changes in slip velocity under high-temperature conditions. J Geophys Res 116, B10405, doi:10.1029/2010JB008062

Takahashi M, Azuma S, Uehara S, Kanagawa K, Inoue A (2013) Contrasting hydrological and mechanical properties of clayey and silty muds cored from the shallow Nankai Trough accretionary prism. Tectonophys 600:63-74

Tanioka Y, Satake K (2001) Detailed coseismic slip distribution of the 1944 Tonankai earthquake estimated from tsunami waveforms. Geophys Res Lett 28:1075-1078

Tembe S, Lockner DA, Wong TF (2010) Effect of clay content and mineralogy on frictional sliding behavior of simulated gouges: binary and ternary mixtures of quartz, illite, and montmorillonite. J Geophys Res 115, B03416, doi:10.1029/ 2009JB006383

Tsutsumi A, Fabbri O, Karpoff AM, Ujiie K, Tsujimoto A (2011) Friction velocity dependence of clay-rich fault material along a megasplay fault in the Nankai subduction zone at intermediate to high velocities. Geophys Res Lett 38, L19301, doi:10.1029/2011GL049314
Ujiie K, Tsutsumi A (2010) High-velocity frictional properties of clay-rich fault gouge in a megasplay fault zone, Nankai subduction zone. Geophys Res Lett 37, L24310, doi:10.1029/2010GL046002

Underwood MB (2007) Sediment inputs to subduction zones: why lithostratigraphy and clay mineralogy matter. In: Dixon TH, Moore JC (eds) The seismogenic zone of subduction thrust faults. Columbia University Press, New York, pp 42-85

Underwood MB, Saito S, Kubo Y, Expedition 322 Scientists (2010) Expedition 322 summary. In: Saito S, Underwood MB, Kubo Y (eds) Expedition 322 Scientists, Proc IODP 322. IODP MI, Tokyo, doi:10.2204/iodp.proc.322.101.2010

\section{doi:10.1186/1880-5981-66-75}

Cite this article as: Takahashi et al:: Frictional properties of the shallow Nankai Trough accretionary sediments dependent on the content of clay minerals. Earth, Planets and Space 2014 66:75.

\section{Submit your manuscript to a SpringerOpen ${ }^{\circ}$ journal and benefit from:}

- Convenient online submission

- Rigorous peer review

- Immediate publication on acceptance

- Open access: articles freely available online

High visibility within the field

- Retaining the copyright to your article

Submit your next manuscript at $\gg$ springeropen.com 